\title{
STUDYING THE CHANGES IN THE MECHANICAL PROPERTIES OF NEUTRON-IRRADIATED CHROMIUM-NICKEL STEELS USING THE "SHEAR PUNCH" METHOD
}

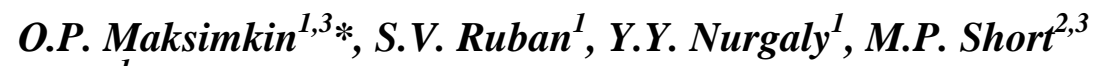 \\ ${ }^{1}$ Institute of Nuclear Physics, Almaty, Kazakhstan; \\ ${ }^{2}$ Dept. of Nuclear Science and Engineering, Massachusetts Institute of Technology, \\ Cambridge, MA, 02139, USA; \\ ${ }^{3}$ National Research Nuclear University MEPhI, Moscow, Russia \\ E-mail: maksimkin@inp.kz
}

\begin{abstract}
Obtaining mechanical properties of neutron irradiated structural materials is made difficult by the high radioactivity of typical specimen sizes. Developing new mechanical tests which obtain the same properties with far smaller specimen sizes would significantly enhance the speed and safety of performing such tests. In this study, we demonstrate the correspondence in mechanical properties between standard, uniaxial tensile testing and a new "Shear Punch" method, involving the shear-based removal of a small $(1 \mathrm{~mm})$ disc of material. Two types of steel, $12 \mathrm{Cr} 18 \mathrm{Ni} 9$ and $08 \mathrm{Cr} 16 \mathrm{Ni1} 1 \mathrm{M} 3$, were irradiated with fast neutrons in the $\mathrm{BN}-350$ reactor up to 23 dpa and shear punch tested between $20 \ldots 300^{\circ} \mathrm{C}$. Excellent correspondence was found between the $0.2 \%$ shear and uniaxial tensile yield stresses, validating this technique as a way to obtain the same mechanical properties with greatly reduced sample size.
\end{abstract}

\section{INTRODUCTION}

In recent years, growing interest has been noted in creating new methods for studying the changes in the mechanical properties of materials irradiated to high doses with neutrons. This interest stems from the fact that most standard testing methods require samples of complex shapes and large sizes, such as uniaxial tensile or fracture toughness specimens. In addition, numerous size effects have been shown and codified in the literature [1], often restricting such tests to large and dangerously radioactive specimens. Performing such studies with radioactive materials incurs serious difficulties for two main reasons. First, researchers usually do not have access to standard sized specimens, and are often forced to use fragments of components or units of arbitrary shape and size. Second, working with radioactive materials brings unique complications caused by time limits of the experiment to minimize researcher dose, requiring the provision of bulky radiation shielding such as hot cells or movable shields. The larger the sample, the thicker the protection must be.

A number of recent innovations help to close the gap between sample size and testability, each with their own advantages and drawbacks. Reduced size specimens can be used for standard tests, such as $1 / 2 \mathrm{~T}-\mathrm{CT}$ specimens in place of 1T-CT for fracture toughness [2], miniaturized tensile specimens $[3,4]$ for yield stress and elongation, and reduced size Charpy coupons for ductile-brittle temperature transition (DBTT) tests [5, 6]. Size effects have been reported throughout the literature at various length scales ranging from the microscale to the macroscale [7-9], requiring calibration of tests with different sizes, which itself is not a major issue. However, even these miniaturized specimens are still rather large, and do not all relieve the issue of high dose. Micro- and nanomechanical tests completely resolve this issue [10], as the focused ion beam (FIB) can be used to section compression pillars [11], tensile specimens [12, 13], and bending specimens [14]. These tests can all be performed in the FIB itself with proper stage attachments, so the FIB chamber acts as an effective biological shield. However, both significant size effects [15] and issues relating to gallium implantation from FIB milling affecting the results $[16,17]$. A technique which blends the smallest possible sample size without changing measured properties in a non-linear fashion is therefore sought, so any potential size effects between full-size and reduced-size specimens can be easily correlated.

Previously a new method of "Shear Punch" testing was proposed for mechanical testing of highly radioactive materials [18-20]. Unlike other methods, this method places relatively few constraints on sample dimensions, as very small discs are extracted from specimens of arbitrary shape and size after sectioning. This allows the same material to be used for transmission electron microscopy (TEM) and to determine key mechanical properties of the material under investigation, such as strength and ductility. One issue arises with this method, as the mode of loading is one of pure shear, rather than in tension. Therefore, some correspondence between measured and desired properties must be established.

The key innovation of the "Shear Punch" method lies in the determination of the engineering $\sigma_{0.2}$ (tensile yield stress) of the irradiated material as a linear function of $\tau_{0.2}$ (shear yield stress). Such a correlation between $\tau_{0.2}$ and $\sigma_{0.2}$ values for some austenitic chromium-nickel alloys has been considered in a number of papers [21-23]. It was shown that a linear dependence is observed between $\tau_{0.2}$ and $\sigma_{0.2}$ with a slope close to two in the general case (Fig. 1). To date, this method has been used for the comparative study of non-irradiated and neutron irradiated structural materials, as an additional method for mechanical tensile testing [24, 25]. Some interesting patterns of radiation effects on reactor steels have been reported using the 
"Shear Punch" method. For example, in [26] this method was used to detect swelling irregularities along the edges of spent fuel assembly ducts made of $08 \mathrm{Cr} 16 \mathrm{Ni11 \textrm {M } 3}$ steel irradiated in the $\mathrm{BN}-350$ reactor. At the same time, the literature shows no studies in which the "Shear Punch" method is used to determine the mechanical properties of irradiated materials at high temperatures, more typical of the operation temperature of commercial reactors.

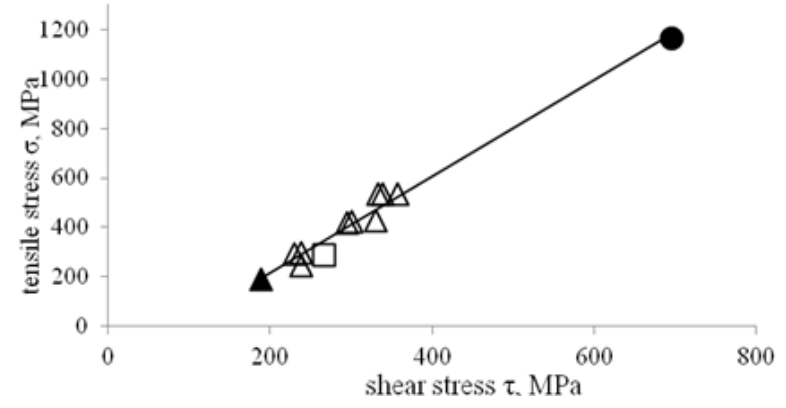

Fig. 1. Linear correlation between yield stresses under uniaxial tension $\left(\sigma_{0,2}\right)$ and shear $\left(\tau_{0,2}\right)$ at $20^{\circ} \mathrm{C}$ :

$\square$-non-irradiated 12Cr18Ni10Ti steel;

$\mathbf{\Delta}$ - non-irradiated $12 \mathrm{Cr} 18 \mathrm{Ni} 9$ steel;

- rolled 12Cr18Ni10Ti steel; $\Delta-12 \mathrm{Cr} 18$ NiloTi steel after austenization and hardening

This study provides the results of experiments performed using the "Shear Punch" method for mechanical testing in the temperature range of $20 \ldots 300^{\circ} \mathrm{C}$. We demonstrate linear correlations between uniaxial tensile and shear yield stresses in $12 \mathrm{Cr} 18 \mathrm{Ni} 9$ and $08 \mathrm{Cr} 16 \mathrm{Ni} 11 \mathrm{M} 3$ steels irradiated with fast neutrons up to 23 dpa. Detailed studies of changes in microstructure, phase composition, and microhardness in the sheared regions of the test specimens reveal the extent and locations of deformation induced by the "Shear Punch" method. Finally, the "Shear Punch" method demonstrates the relatively higher radiation resistance of $08 \mathrm{Cr} 16 \mathrm{Ni} 11 \mathrm{M} 3$ steel, validating its wider use as an alternative method to obtain key mechanical properties with far smaller specimens, and without resorting to micro- or nanomechanical techniques.

\section{METHODS}

Flat specimens of two austenitic chromium-nickel stainless steels were examined in this study, $12 \mathrm{Cr} 18 \mathrm{Ni} 9$ (an AISI 304SS analogue) and 08Cr16Ni11M3 (an AISI 316SS analogue). Compositions of the two steels used in this study are given in Tabl. 1. 12Cr18Ni9 specimens in the form of $290 \ldots 390 \mu \mathrm{m}$ thick discs were first annealed at a temperature of $1050{ }^{\circ} \mathrm{C}$ for $30 \mathrm{~min}$, followed by irradiation in the WWR-K reactor to neutron fluences of $1.9 \cdot 10^{19}$ and $9 \cdot 10^{19} \mathrm{n} / \mathrm{cm}^{2}$ at $\mathrm{T}_{\text {irrad }} \sim 80^{\circ} \mathrm{C}$. In addition, the core of a WWR-K automatic control (AC) rod, also made of $12 \mathrm{Cr} 18 \mathrm{Ni} 9 \mathrm{Ti}$, was studied after irradiation for 25 years. As a result the lower end of this item received a neutron fluence of $1.3 \cdot 10^{22} \mathrm{n} / \mathrm{cm}^{2}$ at $\mathrm{T}_{\text {irrad }} \sim 80^{\circ} \mathrm{C}$, corresponding to an NRT-calculated dose of $5 \mathrm{dpa}$. Finally, $10 \times 50 \mathrm{~mm}$ specimens of $08 \mathrm{Cr} 16 \mathrm{Ni} 11 \mathrm{M} 3$ steel were cut from the edges of fuel assembly (FA) ducts of the BN-350 reactor from various core elevations. Tabl. 2 shows the neutron irradiation parameters of $08 \mathrm{Cr} 16 \mathrm{Ni} 11 \mathrm{M} 3$ steel specimens from these FA ducts. Samples with close irradiation temperatures, but with different doses, were specifically sought as shown in Tabl. 2 . Initially, the blanks for all samples were plates $50 \times 10 \times 2 \mathrm{~mm}$, cut by wire EDM into fragments $4 \times 10 \mathrm{~mm}$ in size and from $200 \ldots 400 \mu \mathrm{m}$ thick. All specimens were first cleaned using conventional methods to clear dirt and corrosion layers for subsequent metallographic studies and determination of microhardness. Grinding was obtained using subsequently finer grits on a polishing machine, followed by electropolishing in a $20 \% \mathrm{HClO}_{4}+80 \% \mathrm{C}_{2} \mathrm{H}_{5} \mathrm{OH}$ electrolyte. Surface quality was monitored with the MII-4 microinterferometer. A surface of mirror finish was obtained.

Table 1

Compositions of steels used in this study, in weight percent

\begin{tabular}{|c|c|c|c|c|c|c|c|}
\hline \multirow{2}{*}{ Steel } & \multicolumn{7}{|c|}{ Element } \\
\cline { 2 - 8 } & $\mathrm{Fe}$ & $\mathrm{Cr}$ & $\mathrm{Ni}$ & $\mathrm{Mn}$ & $\mathrm{Nb}$ & $\mathrm{Mo}$ & Others \\
\hline $08 \mathrm{Cr} 16 \mathrm{Ni11M} 3$ & Bal. & $17.5 \ldots 0.3$ & $11.1 \ldots 0.3$ & $1.5 \ldots 0.9$ & $1.65 \ldots 0.0$ & $0.052 \ldots 0.007$ & $\mathrm{Cu}:<0.15, \mathrm{Zn}: 0.38, \mathrm{Ti}:<0.2$ \\
\hline 12Cr18Ni9 & Bal. & $17 \ldots 19$ & 7.56 & 1.96 & - & - & $\mathrm{Si}:<0.8, \mathrm{~S}:<0.2, \mathrm{P}: 0.35$ \\
\hline
\end{tabular}

Table 2

Irradiation parameters for samples of $08 \mathrm{Cr} 16 \mathrm{Ni} 11 \mathrm{M} 3$ steel from the $\mathrm{BN}-350$ reactor

\begin{tabular}{|c|c|c|c|}
\hline FA marking & Core Height, $\mathrm{mm}$ & Dose, $\mathrm{dpa}$ & $\mathrm{T},{ }^{\circ} \mathrm{C}$ \\
\hline H-214(2) & -500 & 7 & 309 \\
\hline H-214(2) & 0 & 15.6 & 337 \\
\hline No.2 & -300 & 23 & 300 \\
\hline
\end{tabular}

Fig. 2 shows a view of the samples (a) and a schematic of the "Shear Punch" mechanical testing device (b), which consists of a matrix of two parallel plates between which a flat sample can be clamped. The plates have a through hole $(\varnothing=1 \mathrm{~mm})$, where a highstrength steel punch is moving under a changing load. This load ranged up to $120 \mathrm{~kg}$ for specimen thickness up to $400 \mu \mathrm{m}$ in this study. In addition, a ceramic-encased metal wire heater was wrapped around the "Shear Punch" device to raise the testing temperature as shown in Fig. 2,c. During high temperature tests, a K-type (chromel-alumel) thermocouple was affixed directly to the specimen by two point spot welding, and the experimental temperature was actively controlled with a UNIT-F51 thermal controller. 

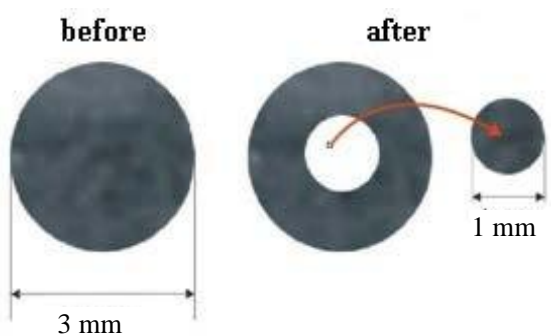

$a$

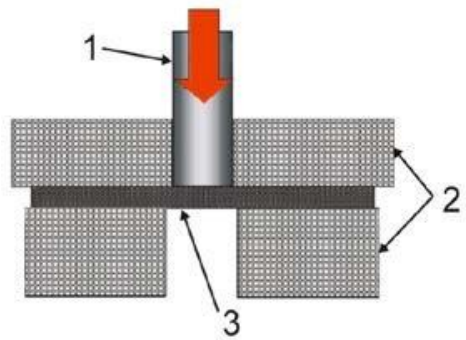

$b$

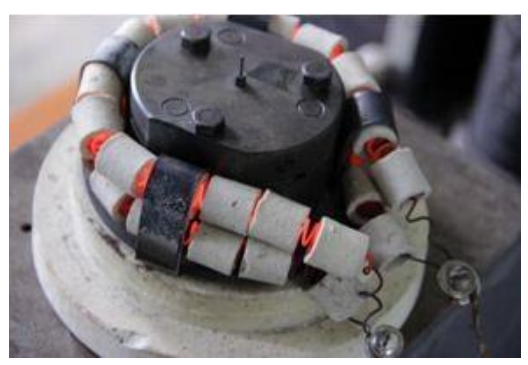

$c$

Fig. 2. Sample before and after the "Shear Punch" test (a, left): Schematic of the assembly for the "Shear Punch" test (b, center): 1 - punch; 2 -plates of the matrix with a clamped sample; 3 -sample. Ceramic heater ring wrapped around the "Shear Punch" apparatus (c, right)

Punch loading and data acquisition were performed on an Instron 1195 universal testing machine. For comparability with the results of other experiments, the displacement rate of the punch was fixed at $0.5 \mathrm{~mm} / \mathrm{min}$. This choice both minimizes the testing time, which is important for working with highly radioactive materials, and obtains a qualitative record of the "compression force - punch displacement" curve. The magnitude of the mechanical shear stress was determined by the following formula:

$$
\tau=F /\left(2 \pi R_{n} d\right),
$$

where $2 R_{n}$ is the diameter of the moving punch, equal to $1 \mathrm{~mm}$, and $\mathrm{d}$ is the sample thickness. At the end of each shear experiment, the amount of ferromagnetic $\alpha$ phase was determined using a Fischer MP-30 ferroprobe in the sample areas near the hole made by the punch, in order to estimate the amount of plastic flow by measuring deformation induced martensite [27]. Microhardnesses were measured using PMT-3 hardness meter, to help quantify work hardening by dislocation creation and pinning alongside deformation-induced martensitic transformation. Microstructures of all deformed specimens were obtained using a Meph-2 metallograph.

\section{RESULTS SIZE EFFECT STUDIES}

Fig. 3 shows load-displacement curves and flow stresses, both yield strength $\left(\sigma_{0.2}\right)$ and ultimate tensile strength $\left(\sigma_{U T S}\right)$, obtained during "Shear Punch" testing of $08 \mathrm{Cr} 16 \mathrm{Ni} 11 \mathrm{M} 3$ steel at room temperature, as functions of specimen thickness. As can be seen Fig. 3,a, the required load is proportional to the thickness of the tested sample. Several identical experiments with different sample thicknesses were performed (see Fig. 3,b) for the case of 08Cr16Ni11M3 steel irradiated to $23 \mathrm{dpa}$. Values of $\sigma_{0.2}$ and $\sigma_{\mathrm{UTS}}$ did not change with specimen thickness by more than $7 \%$ when varying the specimen thickness by a factor of up to two. As a result, it has been established that for $290 \ldots 400 \mu \mathrm{m}$ thick samples, the material properties of interest practically do not change, and thus samples of these thicknesses were used in subsequent experiments to determine the mechanical properties of the irradiated materials using the "Shear Punch" method.

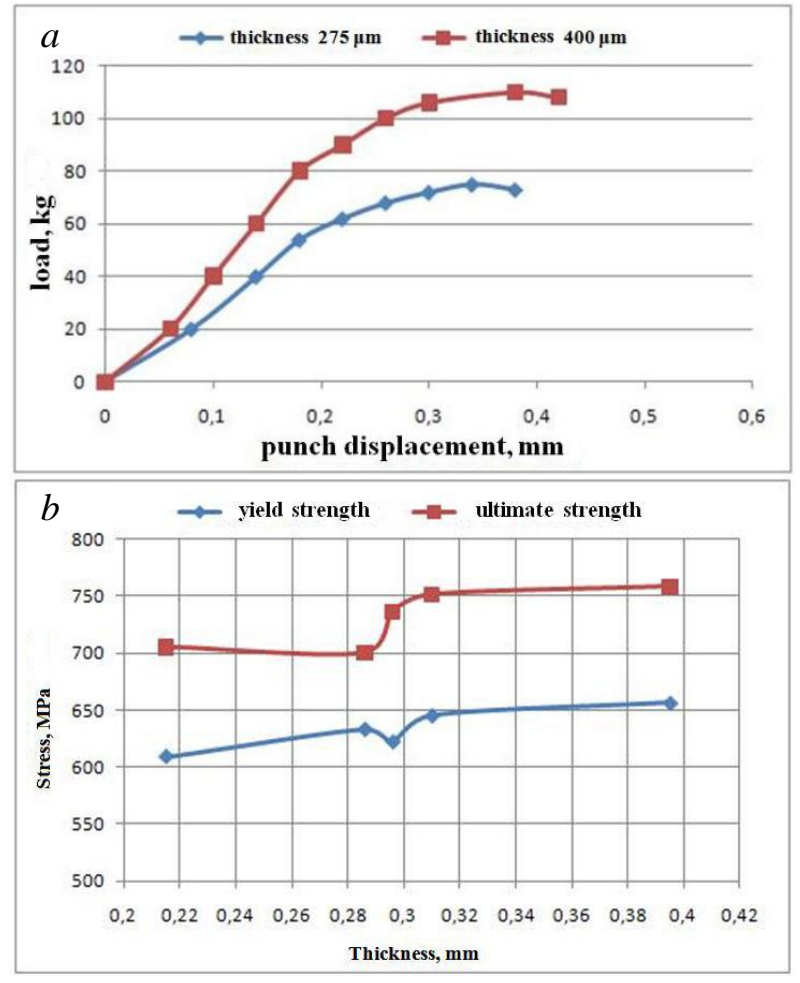

Fig. 3. Load-punch displacement curves of "Shear Punch" tested samples of 08Cr16Ni11M3 steel of different thickness irradiated to $23 \mathrm{dpa}(\mathrm{a}) . \sigma_{0.2}$ and $\sigma_{U T S}$ of 08Cr16Ni11M3 steel (specimen No. 2 in Tabl. 2) irradiated to 23 dpa as a function of specimen thickness (b). All testing was performed at room temperature

\section{Cr18Ni9 STEEL MECHANICAL TESTING}

Fig. 4 shows experimental stress-punch displacement curves obtained by "Shear Punch" testing of non-irradiated and irradiated $12 \mathrm{Cr} 18 \mathrm{Ni} 9$ steel at test temperatures of 20,100 , and $250{ }^{\circ} \mathrm{C}$. It can be seen that the strength of $12 \mathrm{Cr} 18 \mathrm{Ni} 9$ steel increases as a result of neutron irradiation, as is expected, but it decreases significantly with increasing test temperature in the interval of $20 \ldots 250{ }^{\circ} \mathrm{C}$. It is expected that lower shear flow stresses, induced by more thermal unlocking of pinned dislocations, is primarily responsible for this change. Curiously, the maximum punch displacement as a crude measure of ductility increased with irradiation for the material tested at $250{ }^{\circ} \mathrm{C}$, while no change was observed at the other testing temperatures. 


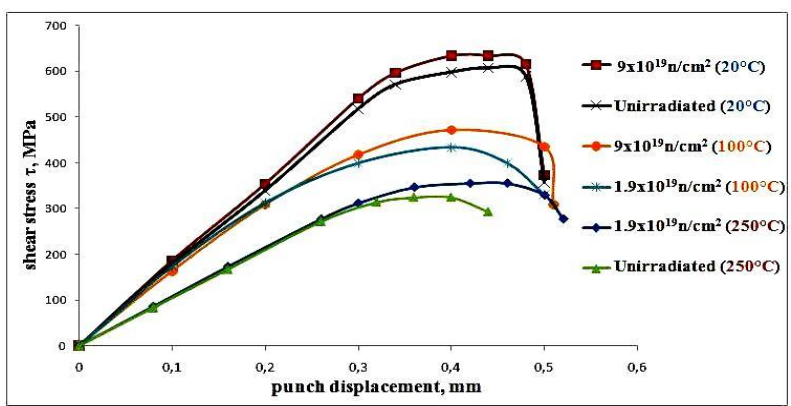

Fig. 4. Dependence of shear stress on punch displacement for non-irradiated and neutron irradiated 12Crl8Ni9 steel as a function of "Shear Punch" testing temperature

Existing mechanical test data [21] were used to determine correlations between the uniaxial tensile yield stress $\sigma_{0.2}$ and the shear yield stress $\tau_{0.2}$, and also between $\sigma_{\mathrm{UTS}}$ under tension and $\tau_{\mathrm{UTS}}$ under shear. The results are shown in Fig. 5. It can be seen that, in both cases, a linear dependence of the tensile stress on the shear stress can be observed. In this case, the proportionality coefficient between ultimate tensile strength and ultimate shear strength is 2.15 , while that between yield strengths is 7.00. The obtained dependence agrees well with the data of other authors, who also performed similar experiments at room temperature [20].

The results of experiments at higher $\left(100\right.$ and $\left.250{ }^{\circ} \mathrm{C}\right)$ temperatures showed that the strength of both nonirradiated and irradiated $12 \mathrm{Cr} 18 \mathrm{Ni} 9$ steel decrease significantly with the testing temperature (Tabl. 3). It can be seen that at $20^{\circ} \mathrm{C}$ the presence of a ferromagnetic $\alpha$-phase is recorded in the region near the hole due to shear plastic deformation [28]. However, this phase is not observed at higher test temperatures of 100 and $250{ }^{\circ} \mathrm{C}$. This can be explained by the fact that for $12 \mathrm{Cr} 18 \mathrm{Ni} 9$ steel the maximum temperature of the $\gamma \rightarrow \alpha$-phase transformation under deformation $(\mathrm{Md})$ is close to $100{ }^{\circ} \mathrm{C}$. It is also seen that with increasing irradiation dose, the amount of the martensitic $\alpha$-phase, induced by the deformation at $20^{\circ} \mathrm{C}$, becomes larger.

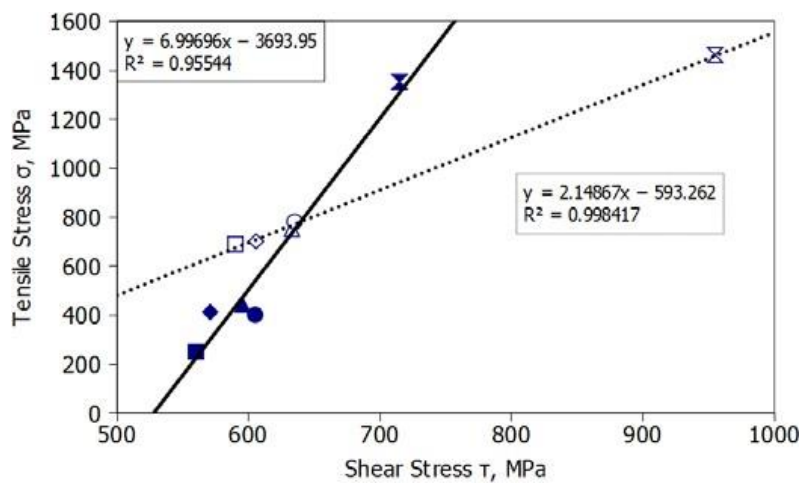

Fig. 5. Correlation between the tensile yield strength $\sigma_{0.2}$ and shear strength $\tau_{0.2}$ (closed symbols), as well as the ultimate strengths under tension $\left(\sigma_{U T S}\right)$ and under shear $\left(\tau_{U T S}\right)$ (open symbols) for $12 \mathrm{Cr} 18 \mathrm{Ni} 9$ steel at $20^{\circ} \mathrm{C}$ :

- non-irradiated; - irradiated at $1.9 \cdot 10^{19} \mathrm{n} / \mathrm{cm}^{2}$; $\Delta$ - irradiated at $9 \cdot 10^{19} \mathrm{n} / \mathrm{cm}^{2}$;

- non-irradiated, annealed at $900{ }^{\circ} \mathrm{C}$ for $30 \mathrm{~min}$; $\mathbf{X}$-after cold plastic deformation by rolling (30...40\%), with no annealing

Table 3

Yield strength $\tau_{0.2}$, ultimate strength $\tau_{\mathrm{UTS}}, \mathrm{MPa}$, and ferromagnetic $\alpha$-phase fraction for $12 \mathrm{Cr} 18 \mathrm{Ni} 9$ steel obtained by "Shear Punching" at $20 \ldots 250^{\circ} \mathrm{C}$, as a function of dose

\begin{tabular}{|c|c|c|c|c|}
\hline $\begin{array}{c}\text { Fluence, } \\
\mathrm{n} / \mathrm{cm}^{2}\end{array}$ & $\mathrm{~T}_{\text {test }},{ }^{\circ} \mathrm{C}$ & $\tau_{0.2}, \mathrm{MPa}$ & $\tau_{\mathrm{UTS}}, \mathrm{MPa}$ & $\begin{array}{c}\text { Amount of } \alpha \text {-phase, } \\
\text { relative units }\end{array}$ \\
\hline \multirow{3}{*}{ Non-irradiated } & 20 & 560 & 590 & 0.38 \\
\cline { 2 - 5 } & 100 & 390 & 420 & 0 \\
\cline { 2 - 5 } & 250 & 300 & 320 & 0 \\
\cline { 2 - 5 } $1.9 \cdot 10^{19}$ & 20 & 570 & 610 & 0 \\
\cline { 2 - 5 } & 100 & 400 & 430 & 0 \\
\hline \multirow{2}{*}{$9 \cdot 10^{19}$} & 250 & 310 & 360 & 0.71 \\
\cline { 2 - 5 } & 20 & 600 & 630 & 0 \\
\hline
\end{tabular}

Metallographic studies of the sample surfaces were performed after mechanical tests in order to better understand features of plastic deformation observed in the "Shear Punch" experiments. Fig. 6 presents photos of the outlet holes made by the punch in the nonirradiated and irradiated. Each photo shows the edges of the holes and outlines of the plastically deformed region, which appeared when the punch passed through the sample. The width of the region subjected to intensive deformation was measured at three different points, and then the average value of the circle width was calculated in microns.

Since measurements were made on the samples of the same thickness, and the diameter of the inner circle of the hole was determined by the size of the punch (and remains unchanged), the width of the ring of deformation (equal to the difference in diameter between the outer and inner circle) depends on the deformation capacity of the material. The widths of the "deformation ring" for non-irradiated steel at 20 and $250{ }^{\circ} \mathrm{C}$ were 133 and $114 \mu \mathrm{m}$, respectively (see Fig. $6, \mathrm{a}, \mathrm{c})$. If we compare the plasticity of the steel non-irradiated and irradiated at $20{ }^{\circ} \mathrm{C}$ (see Fig. 6,a,b), we can note a significant $(41 \%)$ decrease in the width of the deformation ring from 133 to $79 \mu \mathrm{m}$ as a result of irradiation. 
One noteworthy aspect of the deformation circle measurements was the expectation that the width of the circle at $250{ }^{\circ} \mathrm{C}$ in the irradiated sample would be less than that in the sample irradiated and tested at $20{ }^{\circ} \mathrm{C}$.

However, measurements showed that there was no significant reduction in ductility between deformation

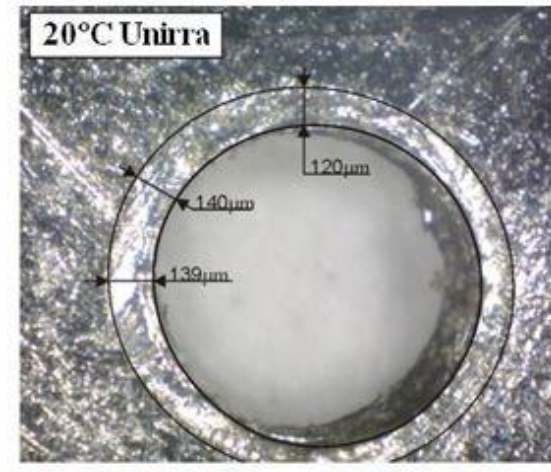

$a$

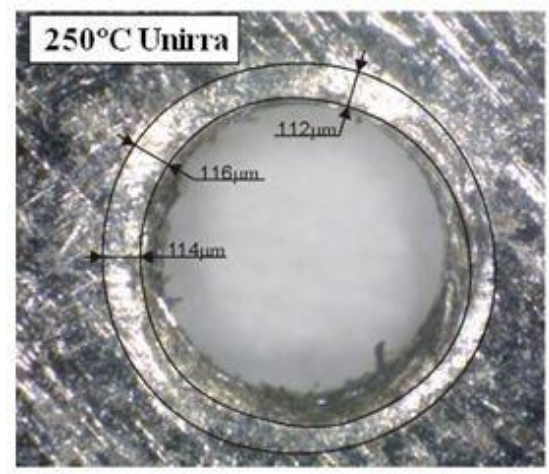

$c$ temperatures, noting the similarity between deformation ring thicknesses in Fig. 6,b,d (83 and $79 \mu \mathrm{m}$, respectively). It can be assumed that there is a certain critical width of the material region involved in shear deformation typical for a given sample size, below which only elastic deformation is observed.
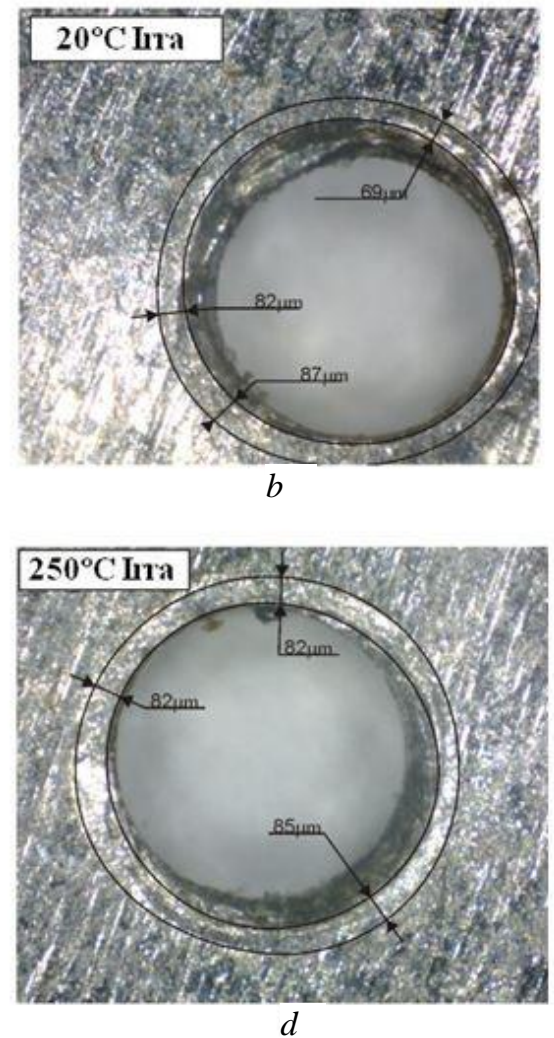

Fig. 6. View of the outlet holes in the samples of $12 \mathrm{Cr} 18 \mathrm{Ni9}$ steel subjected to Shear Punching. Areas subjected to plastic deformation are marked with circles: a-non-irradiated at $20^{\circ} \mathrm{C} ; \mathrm{b}-1.9 \cdot 10^{19} \mathrm{n} / \mathrm{cm}^{2}$ at $20{ }^{\circ} \mathrm{C}$; $c$-non-irradiated at $250{ }^{\circ} \mathrm{C} ; \mathrm{d}-1.9 \cdot 10^{19} \mathrm{n} / \mathrm{cm}^{2}$ at $250^{\circ} \mathrm{C}$

Considering that microhardness $(\mathrm{Hm})$ is an indicator of the degree of plastic deformation, $\mathrm{H} \mu$ measurements were made in the deformation ring regions after photographing the samples. Fig. 7 shows the distribution of microhardness values in the deformation ring for nonirradiated and irradiated $12 \mathrm{Cr} 18 \mathrm{Ni} 9$ steel, before and after annealing at $450{ }^{\circ} \mathrm{C}$.

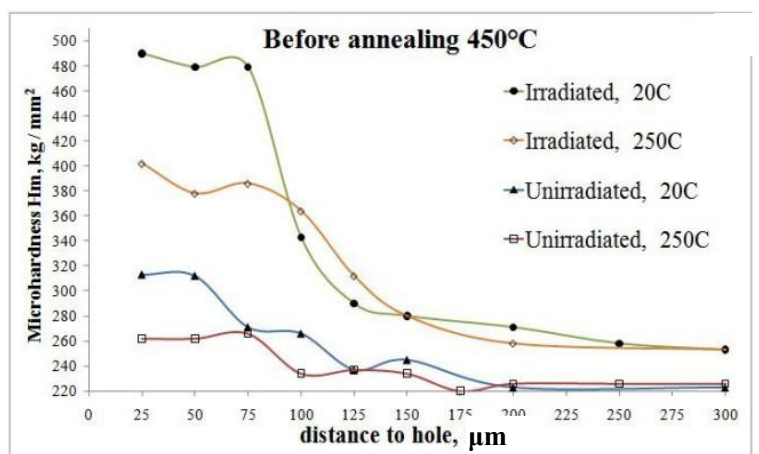

$a$

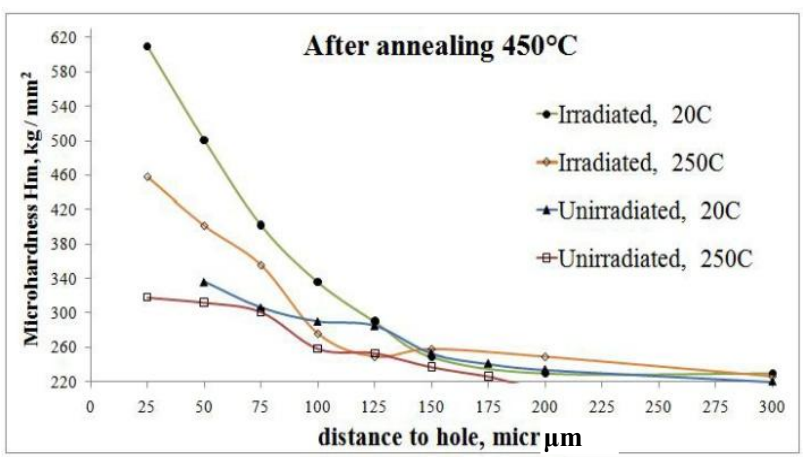

b

Fig. 7. Distribution of microhardness (a) before and $(b)$ after annealing in non-irradiated and irradiated $\left(\Phi=1.9 \cdot 10^{19} \mathrm{n} / \mathrm{cm}^{2}\right) 12 \mathrm{Cr} 18 \mathrm{Ni}$ s steel after "Shear Punch" testing, as a function of the distance from the edge of the hole produced by the punch

We can see from Fig. 7,a that the microhardness is highest at the edge of the holes, and monotonically decreases out to $100 \ldots 150 \mu \mathrm{m}$ from the edge, where it reaches the average values for the non-deformed region. When comparing the patterns of microhardness distributions of the materials tested at $20{ }^{\circ} \mathrm{C}$, we can see 
that for irradiated $12 \mathrm{Cr} 18 \mathrm{Ni} 9$ steel there is a clear boundary of the deformed region $(\sim 100 \mu \mathrm{m})$, where the microhardness reaches $500 \mathrm{~kg} / \mathrm{mm}^{2}$. A higher microhardness with respect to the non- irradiated sample is also maintained at a testing temperature of $250{ }^{\circ} \mathrm{C}$. Specimens following "Shear Punch" testing were then annealed at $450{ }^{\circ} \mathrm{C}$ for $30 \mathrm{~min}$, and microhardness measurements were retaken (see Fig. 7,b). All values of microhardness $(\mathrm{Hm})$ increased within the deformation rings. The greatest increase in $\mathrm{Hm}$ was observed in the irradiated specimen tested at $20^{\circ} \mathrm{C}$, near the edge of the hole.

Table 4

Mechanical properties of $12 \mathrm{Cr} 18 \mathrm{Ni}$ TTi steel subjected to irradiation

and subsequent isochronous annealing

\begin{tabular}{|c|c|c|}
\hline Steel state & $\tau_{0.2}, \mathrm{~kg} / \mathrm{mm}^{2}$ & $\sigma_{0.2}, \mathrm{~kg} / \mathrm{mm}{ }^{2}$ \\
\hline Irradiation with no annealing & 61 & 100 \\
\hline Irradiation + annealing at $450^{\circ} \mathrm{C}, 1$ hour & 35 & 50 \\
\hline Irradiation + annealing at $650^{\circ} \mathrm{C}, 1$ hour & 26 & 33 \\
\hline Irradiation + annealing at $750^{\circ} \mathrm{C}, 1$ hour & 18 & 21 \\
\hline Irradiation + annealing at $850^{\circ} \mathrm{C}, 1$ hour & 20.5 & 20 \\
\hline Irradiation + annealing at $950^{\circ} \mathrm{C}, 1$ hour & 20 & $18 \ldots 20$ \\
\hline Non-irradiated steel, annealing at $1050^{\circ} \mathrm{C}$, & 20 & 20 \\
\hline 30 min (for comparison) & & \\
\hline
\end{tabular}

Mechanical tests of specimens irradiated to $5 \mathrm{dpa}$ were also carried out at room temperature and at a $0.8 \mathrm{~mm} / \mathrm{min}$ rate of punch movement. The samples, subjected to hourly isochronous annealing, were iteratively tested in the "Shear Punch" following each annealing step. The maximum systematic error in determining the shear stress $\tau$ was recorded at four percent. The obtained results are shown in Fig. 8 and in Tabl. 4. Uniaxial tensile yield stresses $\left(\sigma_{0.2}\right)$ were found using the $\sigma-\tau$ correlation previously obtained in Fig. 5 .

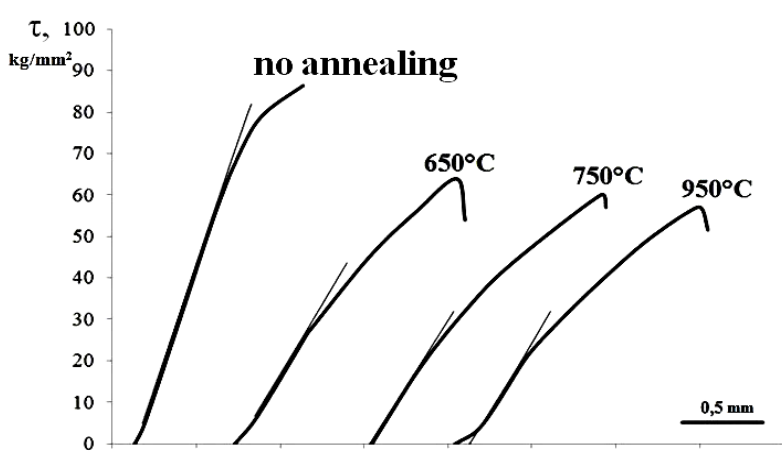

$\Delta l-\cdots$

Fig. 8. Curves of shear stress $\tau$ vs. punch displacement $\Delta l$ for irradiated $12 \mathrm{Cr} 18 \mathrm{Ni} 9 \mathrm{Ti}$ steel subjected to irradiation and isochronous 1-hour annealing

\section{Cr16Ni11M3 STEEL MECHANICAL TESTING}

Fig. 9 shows the changes in $\sigma_{0.2}$ (a) and $\sigma_{\text {UTS }}(\mathrm{b})$ as functions of irradiation dose $(7 \ldots 23 \mathrm{dpa})$ and test temperature $\left(20 \ldots 300^{\circ} \mathrm{C}\right)$ using the "Shear Punch" method for $08 \mathrm{Cr} 16 \mathrm{Ni} 11 \mathrm{M} 3$ steel. A subset of these the samples had been tested earlier at $20^{\circ} \mathrm{C}$ [26]. Fig. 9,a,b shows that both values monotonically decrease with testing temperature, while higher irradiation doses increase strength beyond $15.6 \mathrm{dpa}$.

These results indicate that the $08 \mathrm{Cr} 16 \mathrm{Ni} 11 \mathrm{M} 3$ steel can retain its mechanical properties within acceptable limits for operating nuclear reactors to at least $15.6 \mathrm{dpa}$, where little to no change is observed.
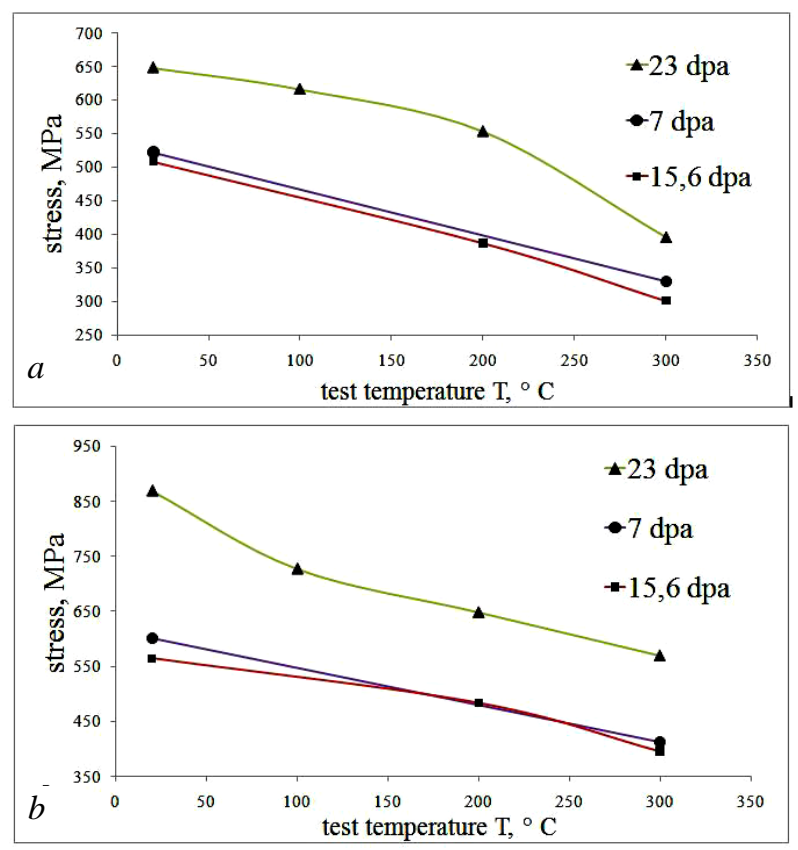

Fig. 9. Values of yield strength (a) and ultimate tensile strength (b) of 08Cr16Ni11M3 steel, determined at different test temperatures and doses using the "Shear Punch" method

They also demonstrate the applicability of the "Shear Punch" method to rapidly determine such quantities, while using a smaller volume of material for testing.

\section{DISCUSSION}

One of the significant drawbacks of the "Shear Punch" method is that the results of mechanical shear tests take the form of "stress-punch movement" curves, with the latter value not directly reflecting the plastic mechanical properties of the material. In our work, we attempted to correct this weakness by performing postdeformation examination of the material near the shear punch hole. The research task was to experimentally determine the value of strain as a function of $t$, the initial 
thickness of the sample, and $\Delta d$, the thickness of the deformed region, in order to calculate the degree of local deformation by the formula:

$$
\varepsilon=\Delta d / t \text {. }
$$

Taking into account the data and the formula above, corrected experimental curves were prepared for $12 \mathrm{Cr} 18 \mathrm{Ni} 9$ steel in - coordinates, as shown in Fig. 10.

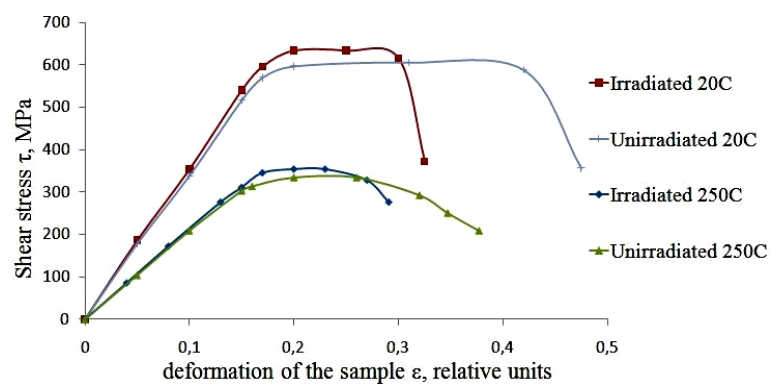

Fig. 10. Shear stress as a function of relative deformation for non-irradiated and neutron-irradiated

$$
\left(1.9 \cdot 10^{19} \mathrm{n} / \mathrm{cm}^{2}\right) 12 \mathrm{Cr} 18 \mathrm{Ni9} \text { steel }
$$

We can see from Fig. 10 that as a result of both irradiation and increased testing temperature, the plasticity determined in the "Shear Punch" experiments is reduced. This is as would be expected from any other standard mechanical property test. A previous study showed high hardness increases in this same steel irradiated to 5 dpa [29], consistent with the decrease in ductility observed in our study. Given the relative agreement between conventional, larger-scale uniaxial tensile tests and the far smaller "Shear Punch" tests, this method is shown to be a satisfactory replacement in a number of common situations. Oftentimes researchers examining irradiated materials are looking for the onset dose for significant radiation-induced embrittlement, not a precise value of ductility vs. a specific set of conditions. In such situations, where the onset dose rather than the change itself is of primary interest, the "Shear Punch" method could be used to more quickly obtain the same information in less time, and with less radiation dose incurred by the researchers. The simplicity of clamping a flat specimen between two plates also requires less manual dexterity than affixing grips in a tensile testing machine, reducing the contact time by the researcher if outside a hot cell, and simplifying procedures even if the test were to take place within a hot cell. Of course flat sample preparation must still take place, though the relative complexity of preparing flat plates compared to other mechanical specimens is still reduced.

In addition, in instances such as those in this study, suitably large and uniform specimens simply did not exist to prepare standard tensile specimens. In such cases the "Shear Punch" method may be preferable even to microtensile experiments, as the probed volume in the "Shear Punch" test (the deformation ring) is far larger than that in a microtensile experiment. This allows for much more material available for post-analysis examination, such as by metallography, microhardness measurements, and quantification of magnetic phase transformations following deformation.

Finally, the geometry of Shear Punched specimens already conforms to TEM sample size standards, allowing for simple thinning pre- or post-testing to proceed with ease. In fact TEM discs are already routinely removed via shear punching [18]. This will allow for the direct correlation of irradiated microstructure with mechanical properties on the same sample. Further work is required to carefully investigate whether the center of a "Shear Punch" specimen, the most likely area for TEM analysis, is unaffected by the "Shear Punch" test.

\section{CONCLUSIONS}

The "Shear Punch" method was applied to study the change in mechanical properties of non-irradiated and neutron-irradiated austenitic $12 \mathrm{Cr} 18 \mathrm{Ni} 9$ (WWR-K) and $08 \mathrm{Cr} 16 \mathrm{Ni} 11 \mathrm{M} 3(\mathrm{BN}-350)$ at test temperatures from $20 \ldots 300{ }^{\circ} \mathrm{C}$. The results of the "Shear Punch" conclude that the $08 \mathrm{Cr} 16 \mathrm{Ni} 11 \mathrm{M} 3$ steel has a sufficiently high radiation resistance at doses up to $23 \mathrm{dpa}$ at $300^{\circ} \mathrm{C}$. Furthermore, linear correlations for both yield strength and ultimate tensile strength between uniaxial tension and shear of specimens was obtained, facilitating the creation of more standard stress-strain curves from the load-punch displacement curves obtained during Shear Punching. This fact allows us to use the new "Shear Punch" technique in the cases when the tension experiments are not possible, for example, when working with highly radioactive and small-size samples.

\section{ACKNOWLEDGEMENTS}

The authors would like to thank researchers that worked at the Laboratory of Radiation Materials Science at the Institute of Nuclear Physics (INP) over the years for their contributions to this publication. The financial support of this work was provided under the National Grant financing Program, Grant No. AP05130527 and Grant No. BR05236400, from the Ministry of Education and Science of the Republic of Kazakhstan.

\section{REFERENCES}

1. T.L. Anderson, R.H. Dodds. Specimen size requirements for fracture toughness testing in the transition region // J. Testing Eval. 1991, v. 19(2), p. 123-134.

2. J.Y. Huang, M.F. Chiang, R.C. Kuo, J.S. Huang, S.L. Jeng. Stress corrosion cracking behavior of dissimilar metal weldments in high temperature water environments // Proc. 15th Intl. Conf. Env. Deg. Mater. Nucl. Power Systems - Water Reactors. Springer, 2011, p. $1105-1125$.

3. M. Gussev, J. Busby, K. Field, M. Sokolov, S. Gray. Role of scale factor during tensile testing of small specimens // Small Specimen Test Techniques: 6th Volume. ASTM International, 2015.

4. J. Džugan, R. Procházka, P. Konopík. MicroTensile Test Technique Development and Application to Mechanical Property Determination // Small Specimen Test Techniques: 6th Volume. ASTM International, 2015.

5. R. Schill, P. Forget, C. Sainte Catherine. Correlation between Charpy-V and sub-size Charpy tests results for an un-irradiated low alloy RPV ferritic steel // ECF13, San Sebastian 2000. 2002. 
6. M.A. Sokolov, R.K. Nanstad. On impact testing of subsize Charpy V-notch type specimens // Effects of Radiation on Materials: 17th Intl. Symposium. ASTM International, 1996.

7. J.R. Greer, W.C. Oliver, W.D. Nix. Size dependence of mechanical properties of gold at the micron scale in the absence of strain gradients // Acta Mater. 2005, v. 53(6), p. 1821-1830.

8. T.T. Zhu, A.J. Bushby, D.J. Dunstan. Materials mechanical size effects: a review // Mater. Technol. 2008, v. 23(4), p. 193-209.

9. A.V. Sergueeva, J. Zhou, B.E. Meacham, D.J. Branagan. Gage length and sample size effect on measured properties during tensile testing // Mater. Sci. Eng. A. 2009, v. 526(1-2), p. 79-8.

10. P. Hosemann, J.G. Swadener, D. Kiener, G.S. Was, S.A. Maloy, N. Li. An exploratory study to determine applicability of nano-hardness and microcompression measurements for yield stress estimation // J. Nucl. Mater. 2008, v. 375(1), p. 135-143.

11. J.A. Sharon, K. Hattar, B.L. Boyce, L.N. Brewer. Compressive Properties of $\langle 110\rangle \mathrm{Cu}$ Micro-Pillars after High-Dose Self-Ion Irradiation // Mater. Res. Lett. 2014, v. 2(2), p. 57-62.

12. C. Howard, C.D. Judge, H.T. Vo, M. Griffiths, P. Hosemann. In Situ SEM Push-to- Pull Micro-tensile Testing of Ex-service Inconel X-750 // Env. Deg. Mater. in Nucl. Power Systems. Springer, 2017, p. 743-757.

13. A. Reichardt, M. Ionescu, J. Davis, L. Edwards, R.P. Harrison, P. Hosemann, D. Bhattacharyya. In situ micro tensile testing of $\mathrm{He}^{+2}$ ion irradiated and implanted single crystal nickel film // Acta Mater. 2015, v. 100, p. 147-154.

14. P. Hosemann, C. Shin, D. Kiener. Small scale mechanical testing of irradiated materials // J. Mater. Res. 2015, v. 30(9), p. 1231-1245.

15. C.P. Frick, B.G. Clark, S. Orso, A.S. Schneider, E. Arzt. Size effect on strength and strain hardening of small-scale [111] nickel compression pillars // Mater. Sci. Eng. A. 2008, v. 489(1-2), p. 319-329.

16. J.R. Greer, J.-Y. Kim, M.J. Burek. The in-situ mechanical testing of nanoscale single-crystalline nanopillars // JOM. 2009, v. 61(12), p. 19.

17. F. Hofmann, E. Tarleton, R.J. Harder, N.W. Phillips, P.-W. Ma, J.N. Clark, I.K. Robinson, B. Abbey, W. Liu, C.E. Beck. 3D lattice distortions and defect structures in ion-implanted nano-crystals // Sci. Rep. 2017, v. 7, p. 45993

18. G.E. Lucas, J.W. Sheckherd, G.R. Odette, and S. Panchanadeeswaran. Shear punch tests for mechanical property measurements in TEM disc-sized specimens // J. Nucl. Mater. 1984, v. 122(1-3), p. 429434.

19. G.L. Hankin, M.B. Toloczko, M L. Hamilton, R.G. Faulkner. Validation of the shear punch-tensile correlation technique using irradiated materials // $\mathrm{J}$. Nucl. Mater. 1998, v. 258, p. 1651-1656.

20. M.L. Hamilton, F.A. Garner, M.B. Toloczko, S.A. Maloy, W.F. Sommer, M.R. James, P.D. Ferguson,
M.R. Louthan Jr. Shear punch and tensile measurements of mechanical property changes induced in various austenitic alloys by high-energy mixed proton and neutron irradiation at low temperatures // J. Nucl. Mater. 2000, v. 283, p. 418-422.

21. M.N. Gusev, O.P. Maksimkin, D.S. Matesov, P.V. Chakrov. Shear Punch - a new device and a method for determining the mechanical properties of highly radioactive materials // Bulletin of NNC. 2001, issue $4, \quad$ p. 43-46. Available at http://old.nnc.kz/images/stories/bulletin/2001/NNC_RK _Bulletin_4_8_2001.pdf

22. R.K. Guduru, K.A. Darling, R. Kishore, R.O. Scattergood, C.C. Koch, and K.L. Murty. Evaluation of mechanical properties using shear-punch testing // Mater. Sci. Eng. A. 2005, v. 395(1-2), p. 307314.

23. V. Karthik, P. Visweswaran, A. Vijayraghavan, K.V. Kasiviswanathan, B. Raj. Tensile - shear correlations obtained from shear punch test technique using a modified experimental approach // J. Nucl. Mater. 2009, v. 393(3), p. 425-432.

24. E.V. Ermakov, M.N. Gusev, N.A. Parhomenko, O.P. Maksimkin. Feature of metallic materials destruction in the Shear Punch testing // Book of papers by young scientists. Kurchatov, 2003, p. 9398. Available at http://ealga.mit.edu/Permanent/2018_Shear_Punch_Pap er/2003_Kurchatov_Young_Scie ntists.pdf.

25. E.B. Rabenberg, B.J. Jaques, B.H. Sencer, F.A. Garner, P.D. Freyer, T. Okita, D.P. Butt. Mechanical behavior of AISI 304SS determined by miniature test methods after neutron irradiation to 28 dpa // J. Nucl. Mater. 2014, v. 448(1-3), p. 315-324.

26. S.V. Ruban, M.A. Zaharov, O.P. Maksimkin. Changes in Physical and Mechanical Properties of 08Cr16Ni11Mo3 Steel after High Irradiation in the BN350 Reactor // Bulletin of NNC. 2015, v. 63(3), p. 51-54. Available at

http://old.nnc.kz/images/stories/bulletin/2015/3_63.pdf.

27. O.P. Maksimkin, O.V. Tivanova. True Characteristics of Strength and Ductility for NeutronIrradiated Metals and Alloys // Effects of Radiation on Materials: 20th International Symposium. ASTM International, 2001.

28. K.V. Tsay, O.P. Maksimkin, L.G. Turubarova, O.V. Rofman, F.A. Garner. Microstructural defect evolution in neutron-irradiated $12 \mathrm{Cr} 18 \mathrm{Ni} 9 \mathrm{Ti}$ stainless steel during subsequent isochronous annealing // $J$. Nucl. Mater. 2013, v. 439(1-3), p. 148-158.

29. K.V. Tsay, M.N. Gusev, et al. The effect of post-radiation annealing on the microstructure and mechanical properties of steel 12X18H10T irradiated in a WWR-K reactor to $5 \mathrm{dpa} / /$ Collection of materials of the international conference "Nuclear and Radiation Physics”. September 26-29, 2005, Almaty, 2006, v. 2, p. 64-175. 


\title{
ИЗУЧЕНИЕ ИЗМЕНЕНИЙ МЕХАНИЧЕСКИХ СВОЙСТВ ВЫСОКООБЛУЧЕННЫХ НЕЙТРОНАМИ ХРОМОНИКЕЛЕВЫХ СТАЛЕЙ C ПРИМЕНЕНИЕМ «SHEAR PUNCH» МЕТОДА
}

\author{
О.П. Максимкин, С.В. Рубан, Е.Е. Нургали, М. Short
}

Представлены и обсуждаются результаты материаловедческих исследований высокорадиоактивных образцов стали 12X18Н9, облученных нейтронами в реакторе ВВР-К, а также образцов стали 08X16Н11М3, вырезанных из стенок чехлов отработавших тепловыделяющих сборок реактора БН-350. Механически испытывали их по схеме «Shear Punch» на установке, адаптированной для проведения экспериментов при температурах в интервале $20 \ldots 300^{\circ} \mathrm{C}$. Было обнаружено отличное соответствие между сдвиговыми напряжениями на $0,2 \%$ сдвига и одноосного растяжения, которое подтверждает эту методику в качестве способа получения тех же механических свойств со значительно уменьшенным размером образца.

\section{ВИВЧЕННЯ ЗМІН МЕХАНІЧНИХ ВЛАСТИВОСТЕЙ ВИСОКООПРОМІНЕНИХ НЕЙТРОНАМИ ХРОМОНІКЕЛЕВИХ СТАЛЕЙ ІЗ ЗАСТОСУВАННЯМ «SHEAR PUNCH» МЕТОДУ}

\author{
О.П. Максимкін, С.В. Рубан, Є.С. Нургалі, М. Short
}

Представлені і обговорюються результати матеріалознавчих досліджень високорадіоактивних зразків сталі $12 \mathrm{X} 18 \mathrm{H} 9$, опромінених нейтронами в реакторі ВВР-К, а також зразків сталі 08X16Н11M3, вирізаних зі стінок чохлів відпрацьованих тепловиділяючих зборок реактора БН-350. Механічно випробували їх за схемою «Shear Punch» на установці, адаптованій для проведення експериментів при температурах в інтервалі $20 \ldots 300^{\circ} \mathrm{C}$. Була виявлена гарна відповідність між зсувними напруженнями на $0,2 \%$ зрушення i одноосного розтягу, яка підтверджує цей метод як спосіб одержання тих же механічних властивостей зі значним зменшенням розміру зразка. 